Interdisciplinary Studies on Ancient Stone

Proceedings of the XI ASMOSIA Conference (Split 2015) 
Publishers:

ARTS ACADEMY IN SPLIT

UNIVERSITY OF SPLIT

and

UNIVERSITY OF SPLIT

FACULTY OF CIVIL ENGINEERING, ARCHITECTURE AND GEODESY

\author{
Technical editor: \\ Kate Bošković \\ English language editor: \\ Graham McMaster \\ Computer pre-press: \\ Nikola Križanac \\ Cover design: \\ Mladen Čulić
}

Cover page:

Sigma shaped mensa of pavonazzetto marble from Diocletian's palace in Split

ISBN 978-953-6617-49-4 (Arts Academy in Split)

ISBN 978-953-6116-75-1 (Faculty of Civil Engineering, Architecture and Geodesy)

e-ISBN 978-953-6617-51-7 (Arts Academy in Split)

e-ISBN 978-953-6116-79-9 (Faculty of Civil Engineering, Architecture and Geodesy)

CIP available at the digital catalogue of the University Library in Split, no 170529005 


\section{ASMOSIA XI \\ Interdisciplinary Studies of Ancient Stone}

Proceedings of the Eleventh International Conference of ASMOSIA, Split, 18-22 May 2015

Edited by

Daniela Matetić Poljak

Katja Marasović
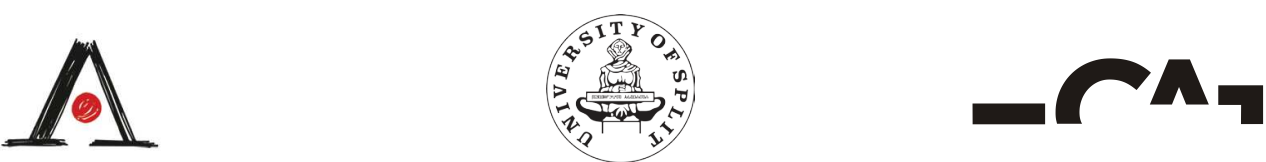

Split, 2018 


\section{Nota bene}

All papers are subjected to an international review.

The quality of the images relies on the quality of the originals provided by the authors. 


\section{APPLICATIONS TO SPECIFIC ARCHEOLOGICAL QUESTIONS - USE OF MARBLE}

Hermaphrodites and Sleeping or Reclining Maenads:

Production Centres and Quarry Marks

Patrizio Pensabene

First Remarks about the Pavement of the Newly Discovered Mithraeum of the Colored Marbles at Ostia and New Investigations on Roman and Late Roman White and Colored Marbles from Insula IV, IX Massimiliano David, Stefano Succi and Marcello Turci

Alabaster. Quarrying and Trade in the Roman World:

Evidence from Pompeii and Herculaneum

Simon J. Barker and Simona Perna

Recent Work on the Stone at the Villa Arianna and the Villa San Marco

(Castellammare di Stabia) and Their Context within the Vesuvian Area

Simon J. Barker and J. Clayton Fant

Marble Wall Decorations from the Imperial Mausoleum $\left(4^{\text {th }} \mathrm{C}\right.$. $)$ and the Basilica of San Lorenzo $\left(5^{\text {th }}\right.$ C.) in Milan: an Update on Colored Marbles in Late Antique Milan Elisabetta Neri, Roberto Bugini and Silvia Gazzoli

Sarcophagus Lids Sawn from their Chests

Dorothy H. Abramitis and John J. Herrmann

The Re-Use of Monolithic Columns in the Invention and Persistence of Roman Architecture

Peter D. De Staebler

The Trade in Small-Size Statues in the Roman Mediterranean:

a Case Study from Alexandria

Patrizio Pensabene and Eleonora Gasparini

The Marble Dedication of Komon, Son of Asklepiades, from Egypt:

Material, Provenance, and Reinforcement of Meaning

Patricia A. Butz

Multiple Reuse of Imported Marble Pedestals at Caesarea Maritima in Israel

Barbara Burrell

Iasos and Iasian Marble between the Late Antique and Early Byzantine Eras 
Thassos, Known Inscriptions with New Data

Tony Kozelj and Manuela Wurch-Kozelj

The Value of Marble in Roman Hispalis: Contextual, Typological and Lithological Analysis of an Assemblage of Large Architectural Elements Recovered at No 17 Goyeneta Street (Seville, Spain)

Ruth Taylor, Oliva Rodríguez, Esther Ontiveros, María Luisa Loza, José Beltrán and Araceli Rodríguez

Giallo Antico in Context. Distribution, Use and Commercial Actors According

to New Stratigraphic Data from the Western Mediterranean $\left(2^{\text {nd }} \mathrm{C}\right.$. Bc - Late $1^{\text {st }} \mathrm{C}$. Ad)

Stefan Ardeleanu

Amethystus: Ancient Properties and Iconographic Selection

Luigi Pedroni

\section{PROVENANCE IDENTIFICATION I: (MARBLE)}

Unraveling the Carrara - Göktepe Entanglement

Walter Prochaska, Donato Attanasio and Matthias Bruno

The Marble of Roman Imperial Portraits

Donato Attanasio, Matthias Bruno, Walter Prochaska and Ali Bahadir Yavuz

Tracing Alabaster (Gypsum or Anhydrite) Artwork Using Trace Element Analysis

and a Multi-Isotope Approach ( $\mathrm{Sr}, \mathrm{S}, \mathrm{O})$

Lise Leroux, Wolfram Kloppmann, Philippe Bromblet, Catherine Guerrot,

Anthony H. Cooper, Pierre-Yves Le Pogam, Dominique Vingtain and Noel Worley

Roman Monolithic Fountains and Thasian Marble

Annewies van den Hoek, Donato Attanasio and John J. Herrmann

Archaeometric Analysis of the Alabaster Thresholds of Villa A, Oplontis

(Torre Annunziata, Italy) and New Sr and Pb Isotopic Data for

Alabastro Ghiaccione del Circeo

Simon J. Barker, Simona Perna, J. Clayton Fant, Lorenzo Lazzarini and Igor M. Villa

Roman Villas of Lake Garda and the Occurrence of Coloured Marbles in the Western Part of "Regio X Venetia et Histria" (Northern Italy)

Roberto Bugini, Luisa Folli and Elisabetta Roffia

Calcitic Marble from Thasos in the North Adriatic Basin:

Ravenna, Aquileia, and Milan

John J. Herrmann, Robert H. Tykot and Annewies van den Hoek

Characterisation of White Marble Objects from the Temple of Apollo

and the House of Augustus (Palatine Hill, Rome)

Francesca Giustini, Mauro Brilli, Enrico Gallocchio and Patrizio Pensabene

Study and Archeometric Analysis of the Marble Elements Found in the Roman Theater at Aeclanum (Mirabella Eclano, Avellino - Italy)

Antonio Mesisca, Lorenzo Lazzarini, Stefano Cancelliere and Monica Salvadori 
Two Imperial Monuments in Puteoli:

Use of Proconnesian Marble in the Domitianic and Trajanic Periods in Campania

Irene Bald Romano, Hans Rupprecht Goette, Donato Attanasio and Walter Prochaska

Coloured Marbles in the Neapolitan Pavements ( $16^{\text {th }}$ And $17^{\text {th }}$ Centuries):

the Church of Santi Severino e Sossio

Roberto Bugini, Luisa Folli and Martino Solito

Roman and Early Byzantine Sarcophagi of Calcitic Marble from Thasos in Italy:

Ostia and Siracusa

Donato Attanasio, John J. Herrmann, Robert H. Tykot and Annewies van den Hoek

Revisiting the Origin and Destination of the Late Antique Marzamemi

'Church Wreck' Cargo

Justin Leidwanger, Scott H. Pike and Andrew Donnelly.

The Marbles of the Sculptures of Felix Romuliana in Serbia

Walter Prochaska and Maja Živić

Calcitic Marble from Thasos and Proconnesos in Nea Anchialos (Thessaly)

and Thessaloniki (Macedonia)

Vincent Barbin, John J. Herrmann, Aristotle Mentzos and Annewies van den Hoek

Architectural Decoration of the Imperial Agora's Porticoes at Iasos

Fulvia Bianchi, Donato Attanasio and Walter Prochaska

The Winged Victory of Samothrace - New Data on the Different Marbles

Used for the Monument from the Sanctuary of the Great Gods

Annie Blanc, Philippe Blanc and Ludovic Laugier

Polychrome Marbles from the Theatre of the Sanctuary of Apollo Pythios

in Gortyna (Crete)

Jacopo Bonetto, Nicolò Mareso and Michele Bueno

Paul the Silentiary, Hagia Sophia, Onyx, Lydia, and Breccia Corallina

John J. Herrmann and Annewies van den Hoek

Incrustations from Colonia Ulpia Traiana (Near Modern Xanten, Germany)

Vilma Ruppiene and Ulrich Schüssler

Stone Objects from Vindobona (Austria) - Petrological Characterization and Provenance of Local Stone in a Historico-Economical Setting

Andreas Rohatsch, Michaela Kronberger, Sophie Insulander,

Martin Mosser and Barbara Hodits

Marbles Discovered on the Site of the Forum of Vaison-la-Romaine (Vaucluse, France):

Preliminary Results

Elsa Roux, Jean-Marc Mignon, Philippe Blanc and Annie Blanc

Updated Characterisation of White Saint-Béat Marble. Discrimination Parameters

from Classical Marbles

Hernando Royo Plumed, Pilar Lapeunte, José Antonio Cuchí,

Mauro Brilli and Marie-Claire Savin 
Grey and Greyish Banded Marbles from the Estremoz Anticline in Lusitania Pilar Lapuente, Trinidad Nogales-Basarrate, Hernando Royo Plumed,

New Data on Spanish Marbles: the Case of Gallaecia (NW Spain)

Anna Gutiérrez Garcia-M., Hernando Royo Plumed and Silvia González Soutelo

A New Roman Imperial Relief Said to Be from Southern Spain:

Problems of Style, Iconography, and Marble Type in Determining Provenance

John Pollini, Pilar Lapuente, Trinidad Nogales-Basarrate and Jerry Podany

Reuse of the Marmora from the Late Roman Palatial Building at Carranque

(Toledo, Spain) in the Visigothic Necropolis

Virginia García-Entero, Anna Gutiérrez Garcia-M. and Sergio Vidal Álvarez

Imperial Porphyry in Roman Britain

David F. Williams

Recycling of Marble: Apollonia/Sozousa/Arsuf (Israel) as a Case Study

Moshe Fischer, Dimitris Tambakopoulos and Yannis Maniatis

Thasian Connections Overseas: Sculpture in the Cyrene Museum (Libya)

Made of Dolomitic Marble from Thasos

John J. Herrmann and Donato Attanasio

Marble on Rome's Southwestern Frontier: Thamugadi and Lambaesis

Robert H. Tykot, Ouahiba Bouzidi, John J. Herrmann and Annewies van den Hoek

Marble and Sculpture at Lepcis Magna (Tripolitania, Libya):

a Preliminary Study Concerning Origin and Workshops

Luisa Musso, Laura Buccino, Matthias Bruno, Donato Attanasio and Walter Prochaska

The Pentelic Marble in the Carnegie Museum of Art Hall of Sculpture,

Pittsburgh, Pennsylvania

Albert D. Kollar

Analysis of Classical Marble Sculptures in the Michael C. Carlos Museum,

Emory University, Atlanta

Robert H. Tykot, John J. Herrmann, Renée Stein, Jasper Gaunt,

Susan Blevins and Anne R. Skinner.

\section{PROVENANCE IDENTIFICATION II: (OTHER STONES)}

Aphrodisias and the Regional Marble Trade. The Scaenae Frons of the Theatre at Nysa

Natalia Toma

The Stones of Felix Romuliana (Gamzigrad, Serbia)

Bojan Djurić, Divna Jovanović, Stefan Pop Lazić and Walter Prochaska

Aspects of Characterisation of Stone Monuments from Southern Pannonia

Branka Migotti 
The Budakalász Travertine Production

Stone Monuments from Carnuntum and Surrounding Areas (Austria) Petrological Characterization and Quarry Location in a Historical Context

Gabrielle Kremer, Isabella Kitz, Beatrix Moshammer, Maria Heinrich and Erich Draganits

Espejón Limestone and Conglomerate (Soria, Spain):

Archaeometric Characterization, Quarrying and Use in Roman Times

Virginia García-Entero, Anna Gutiérrez Garcia-M, Sergio Vidal Álvarez,

María J. Peréx Agorreta and Eva Zarco Martínez

The Use of Alcover Stone in Roman Times (Tarraco, Hispania Citerior).

Contributions to the Officina Lapidaria Tarraconensis

Diana Gorostidi Pi, Jordi López Vilar and Anna Gutiérrez Garcia-M.

\section{ADVANCES IN PROVENANCE TECHNIQUES,} METHODOLOGIES AND DATABASES

Grainautline - a Supervised Grain Boundary Extraction Tool

Supported by Image Processing and Pattern Recognition

Kristóf Csorba, Lilla Barancsuk, Balázs Székely and Judit Zöldföldi

A Database and GIS Project about Quarrying, Circulation and Use of Stone

During the Roman Age in Regio X - Venetia et Histria.

The Case Study of the Euganean Trachyte

Caterine Previato and Arturo Zara

\section{QUARRIES AND GEOLOGY}

The Distribution of Troad Granite Columns as Evidence for Reconstructing the Management of Their Production

Patrizio Pensabene, Javier Á. Domingo and Isabel Rodà

Ancient Quarries and Stonemasonry in Northern Choria Considiana

Hale Güney

Polychromy in Larisaean Quarries and its Relation to Architectural Conception

Gizem Mater and Ertunç Denktaş

Euromos of Caria: the Origin of an Hitherto Unknown Grey Veined Stepped Marble of Roman Antiquity

Matthias Bruno, Donato Attanasio, Walter Prochaska and Ali Bahadir Yavuz

Unknown Painted Quarry Inscriptions from Bacakale at Docimium (Turkey)

Matthias Bruno

The Green Schist Marble Stone of Jebel El Hairech (North West of Tunisia):

a Multi-Analytical Approach and its Uses in Antiquity

Ameur Younès, Mohamed Gaied and Wissem Gallala

Building Materials and the Ancient Quarries at Thamugadi (East of Algeria),

Case Study: Sandstone and Limestone

Younès Rezkallah and Ramdane Marmi 
The Local Quarries of the Ancient Roman City of Valeria (Cuenca, Spain)

Javier Atienza Fuente

The Stone and Ancient Quarries of Montjuïc Mountain (Barcelona, Spain)

Aureli Álvarez

Notae Lapicidinarum: Preliminary Considerations about the Quarry Marks

from the Provincial Forum of Tarraco

Maria Serena Vinci

The Different Steps of the Rough-Hewing on a Monumental Sculpture

at the Greek Archaic Period: the Unfinished Kouros of Thasos

Danièle Braunstein

A Review of Copying Techniques in Greco-Roman Sculpture

Séverine Moureaud

Labour Forces at Imperial Quarries

Ben Russell

Social Position of Craftsmen inside the Stone and Marble Processing Trades

in the Light of Diocletian's Edict on Prices

Krešimir Bosnić and Branko Matulić

6. STONE PROPERTIES, WEATHERING EFFECTS AND RESTORATION,

AS RELATED TO DIAGNOSIS PROBLEMS, MATCHING

OF STONE FRAGMENTS AND AUTHENTICITY

Methods of Consolidation and Protection of Pentelic Marble

Maria Apostolopoulou, Elissavet Drakopoulou, Maria Karoglou and Asterios Bakolas

\section{PIGMENTS AND PAINTINGS ON MARBLE}

Painting and Sculpture Conservation in Two Gallo-Roman Temples in Picardy (France):

Champlieu and Pont-Sainte-Maxence

Véronique Brunet-Gaston and Christophe Gaston

The Use of Colour on Roman Marble Sarcophagi

Eliana Siotto

New Evidence for Ancient Gilding and Historic Restorations on a Portrait of Antinous in the San Antonio Museum of Art

Jessica Powers, Mark Abbe, Michelle Bushey and Scott H. Pike

Schists and Pigments from Ancient Swat (Khyber Pukhtunkhwa, Pakistan)

Francesco Mariottini, Gianluca Vignaroli, Maurizio Mariottini and Mauro Roma 793

8. SPECIAL THEME SESSION: „THE USE OF MARBLE AND LIMESTONE IN THE ADRIATIC BASIN IN ANTIQUITY"

Marble Sarcophagi of Roman Dalmatia Material - Provenance - Workmanship

Guntram Koch 809 
Funerary Monuments and Quarry Management in Middle Dalmatia

Marble Revetments of Diocletian's Palace

Katja Marasović and Vinka Marinković .

The Use of Limestones as Construction Materials for the Mosaics of Diocletian's Palace

Branko Matulić, Domagoj Mudronja and Krešimir Bosnić

Restoration of the Peristyle of Diocletian's Palace in Split

Goran Nikšić

Marble Slabs Used at the Archaeological Site of Sorna near Poreč Istria - Croatia

Đeni Gobić-Bravar

Ancient Marbles from the Villa in Verige Bay, Brijuni Island, Croatia

Mira Pavletić and Đeni Gobić-Bravar

Notes on Early Christian Ambos and Altars in the Light of some Fragments

from the Islands of Pag and Rab

Mirja Jarak

The Marbles in the Chapel of the Blessed John of Trogir

in the Cathedral of St. Lawrence at Trogir

Đeni Gobić-Bravar and Daniela Matetić Poljak

The Use of Limestone in the Roman Province of Dalmatia

Edisa Lozić and Igor Rižnar

The Extraction and Use of Limestone in Istria in Antiquity

Klara Buršić-Matijašić and Robert Matijašić

Aurisina Limestone in the Roman Age:

from Karst Quarries to the Cities of the Adriatic Basin

Caterina Previato

The Remains of Infrastructural Facilities

of the Ancient Quarries on Zadar Islands (Croatia)

Mate Parica

The Impact of Local Geomorphological and Geological Features

of the Area for the Construction of the Burnum Amphitheatre

Miroslav Glavičić and Uroš Stepišnik

Roman Quarry Klis Kosa near Salona

Ivan Alduk

Marmore Lavdata Brattia

Miona Miliša and Vinka Marinković

Quarries of the Lumbarda Archipelago

Ivka Lipanović and Vinka Marinković 
Island of Korčula - Importer and Exporter of Stone in Antiquity

Mate Parica and Igor Borzić

Faux Marbling Motifs in Early Christian Frescoes

in Central and South Dalmatia: Preliminary Report

Tonči Borovac, Antonija Gluhan and Nikola Radošević 


\title{
REUSE OF THE MARMORA FROM THE LATE ROMAN PALATIAL BUILDING AT CARRANQUE (TOLEDO, SPAIN) IN THE VISIGOTHIC NECROPOLIS ${ }^{1}$
}

\author{
Virginia García-Entero ${ }^{1}$, Anna Gutiérrez Garcia-M. ${ }^{2}$ and Sergio Vidal Álvarez ${ }^{3}$ \\ ${ }^{1}$ Universidad Nacional de Educación a Distancia (UNED), Madrid, Spain (vgarciaentero@geo.uned.es) \\ ${ }^{2}$ Institut de Recherche sur les ArchéoMATériaux (IRAMAT) - Centre de Recherche en Physique Appliquée à l’Archéologie \\ (CRP2A), Université de Bordeaux Montaigne, Bordeaux, France (anna.gutierrez@u-bordeaux-montaigne.fr) \\ ${ }^{3}$ Museo Arqueológico Nacional (MAN), Madrid, Spain (sergio.vidal@cultura.gob.es)
}

\begin{abstract}
The archaeological site of Carranque (Toledo, Spain) is one of the most important Hispano-Roman sites in terms of the use of marmora during the late Roman Empire. The research carried out since 2004 at this site has shed light on the extent of the use of more than forty types of marmora (from the most important Mediterranean and Hispanic quarries) to decorate a prominent palatial building built in the late $4^{\text {th }}$ century AD and which has been the object of recent studies and publications. The work we present now focuses on the reuse of marmora from this Late Roman building in the construction of tombs of the necropolis established in Visigothic times $\left(6^{\text {th }}-7^{\text {th }}\right.$ centuries AD).
\end{abstract}

Keywords

Carranque, marmor reuse, Visigothic necropolis

\section{Introduction}

The archaeological site of Carranque is located on the northern part of the current province of Toledo, bordering on the province of Madrid, in La Sagra region. In ancient times, it belonged to the conventus Carthaginensis (Tarraconensis province) and to the Carthaginensis province after Diocletian's administrative reform. The site was discovered by chance in 1983 during agricultural work and has been the object of archaeological excavations since 1986'. In 2003 the site

The first stage of the investigation of the site was carried out between 1986 and 2003 under the direction of D. Fernández-Galiano and B. Patón Lorca. Its result was the production of an abundant bibliography, mainly focused on the iconography of mosaics of the so-called villa of Materno (for a summary of the works carried out, see Carranque. Centro de Hispania romana, was opened to the public as part of the Red de Parques Arqueológicos de la Junta de Comunidades de CastillaLa Mancha (Castilla-La Mancha Archaeological Parks Department). The site was established on a wide fluvial terrace on the left bank of the Guadarrama River and covers an area of $c .18$ hectares. Several buildings and structures have been found since 1986. Among them, three buildings stand out: the villa of Maternus, a funerary building (mausoleum) and the Late Roman palatial building (Fig. 1). Other, still only partially known, buildings existed over the wide terrace. Among them, it is possible to recognize the pars fructuaria of the villa. It was related to olive oil and wine production and it has been under investigation in recent years (GARCÍA-ENTERO et al. 2012).

The study of the marmora of Carranque is one of the key objectives of the current research group, which has been working on it since 2004. The vast volume of material recovered in the Late Roman palatial building,

Guadalajara, 2001). Since 2004, C. Fernández Ochoa (UAM) and V. García-Entero (UNED) are in charge of the scientific direction of this site.

2

This paper is part of the Project "Marmora Hispaniae. The Quarrying, Use and Trade of Espejón Limestone in Roman and Late Antique Hispania" (HAR2013-44971) funded by the Ministerio de Economía y Competitividad of Spain directed by V. García-Entero. It is also part of the Project "Estudio de los materiales arqueológicos procedentes de las excavaciones desarrolladas en el edificio palacial del yacimiento de Carranque (Toledo) durante las campañas de 2009 a 2011" led in 2014 by C. Fernández Ochoa and V. García-Entero, and funded by Dirección General de Cultura de la Consejería de Educación, Cultura y Deportes de la JCCM; the cooperation of A. Gutiérrez Garcia-M. has been possible thanks to the "Lapides et Marmora Hispaniae" project of the LabEx Sciences Archéologiques de Bordeaux programme supported by the ANR ( $n^{\circ}$ ANR-10LABX-52). 


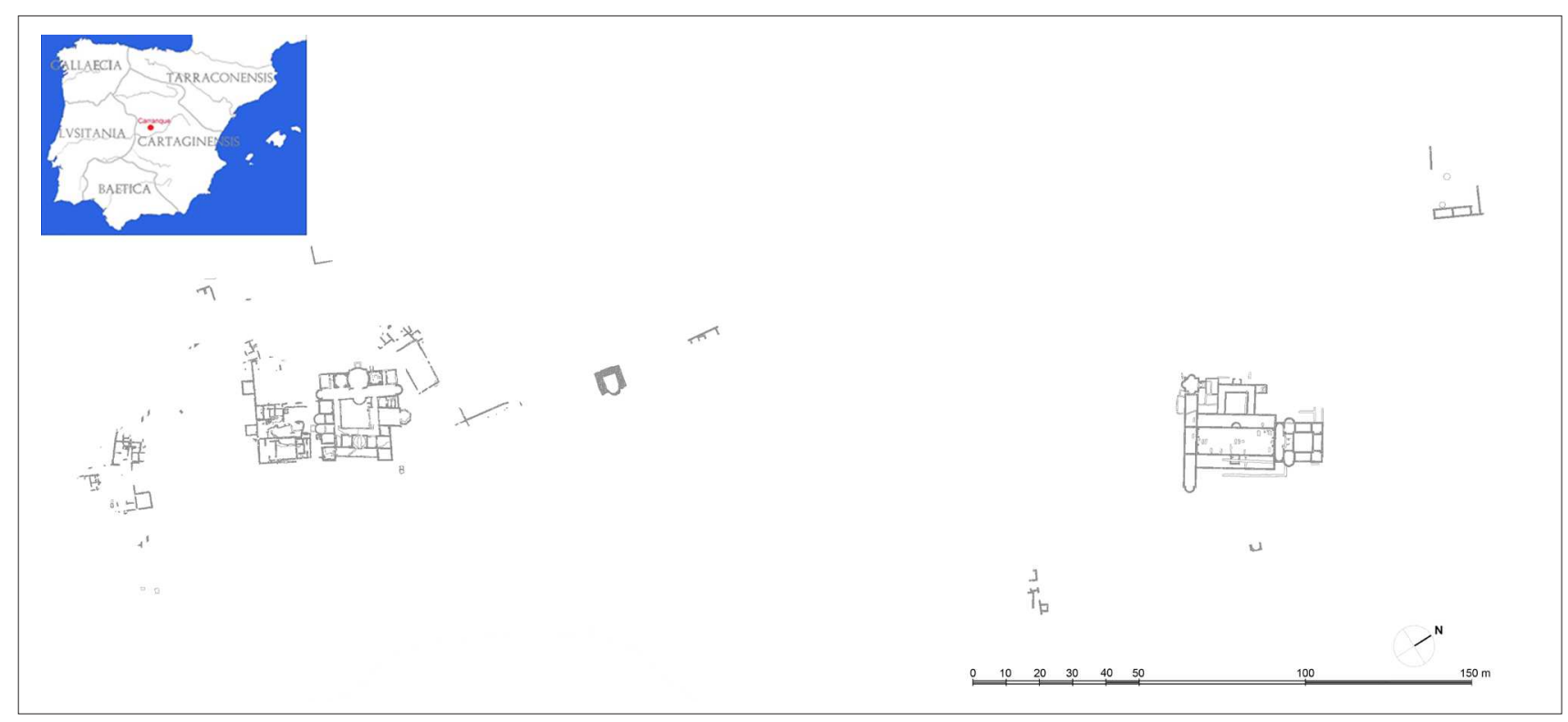

Fig. 1. Plan of the Roman site of Carranque (Toledo, Spain) with location of the site in the Iberian peninsula

several hundreds of thousands of fragments, determines the phases of the study. We have dedicated the first phase to the classification and identification ${ }^{3}$ of the more than forty types of marmora employed in the decoration program of this important building. This wide array of materials and the presence of some imported types extremely uncommon in Hispania confirms that the archaeological site of Carranque is one of the most important Hispano-Roman sites in terms of the use of marmora during the Late Roman Empire (GARCÍA-ENTERO, VIDAL 2007; 2012; GARCÍA-ENTERO et al. 2008).

\section{The Late Roman palatial building and the Visigothic necropolis}

The excavation works carried out between 2009 and 2011 focused on the large, Late Roman palatial building. They confirm that this area of the site was occupied over a long span of time, from the construction of the palatial building in the Late Roman period (late $4^{\text {th }}$ century $\mathrm{AD})$ to the final destruction of the last standing remains of its walls in the early $20^{\text {th }}$ century. Especially noteworthy are the periods of occupation in Visigothic and medieval times (GARCÍA-ENTERO et al. 2014). The palace is located on the enclave's lower terrace, a few meters away

3 Including detailed macroscopic examination of every single fragment and the archaeometric characterization of a large selection of them. To these, we have applied a multimethod analytical protocol consisting of petrography (optical transmitted light microscopy), cathodoluminescence and mass spectrometry isotopic relations. ÀLVAREZ et al. 2006; 2007; RODÀ et al. 2009; 2010. from the Guadarrama River. From an architectonic point of view, the building consists of a northern section of centralized plan, with eight smaller spaces arranged around a central space of bigger dimensions (Fig. 2). Two of these minor rooms are closed with exedras. A double-apsed vestibule precedes the entire section, leading to a big open patio. Two porticoed corridors flank the patio to east and west. These corridors are cut off in their central area by the presence of an apsed space -to the west- and a quadrangular space -to the east. On the southern flank, the building closes by means of a long section running perpendicular to the patio, closed on the eastern end by an exedra, and on the western end by a four-lobed building. Finally, there is a group of rooms arranged around a U-shaped corridor next to the western flank of the West portico.

This building is undoubtedly the most sumptuous among those documented in Carranque in terms of quantity and variety of the marmora used in its decoration program (pavement and revetment slabs and opera sectil$i a$, architectural molding elements, pilaster and column shafts, capitals, furniture, etc.). Thus, the use of porfido rosso, porfido nero, porfido verde egiziano, granito verde della sedia di San Lorenzo, granito bianco e nero, granito rosso from Asuán, granito verde a erbetta, serpentino, porfido vitelli, breccia verde di Sparta, rosso antico, cipollino rosso Taenarium, bigio morato/nero antico, verde antico, cipollino, fior di pesco, breccia di Sciro o di Settebassi, portasanta, marmor Thasium, marmor parium -lapis lychnites-, pavonazzetto, breccia corallina, africano, marmor carium o iassense, rosso brecciato, giallo antico, giallo brecciato, Estremoz marble, Almadén de la Plata marble, Espejón limestone, and other Hispanic marmora has been attested (Fig. 3) (GARCÍA-ENTERO, VIDAL 2007, 2012; 

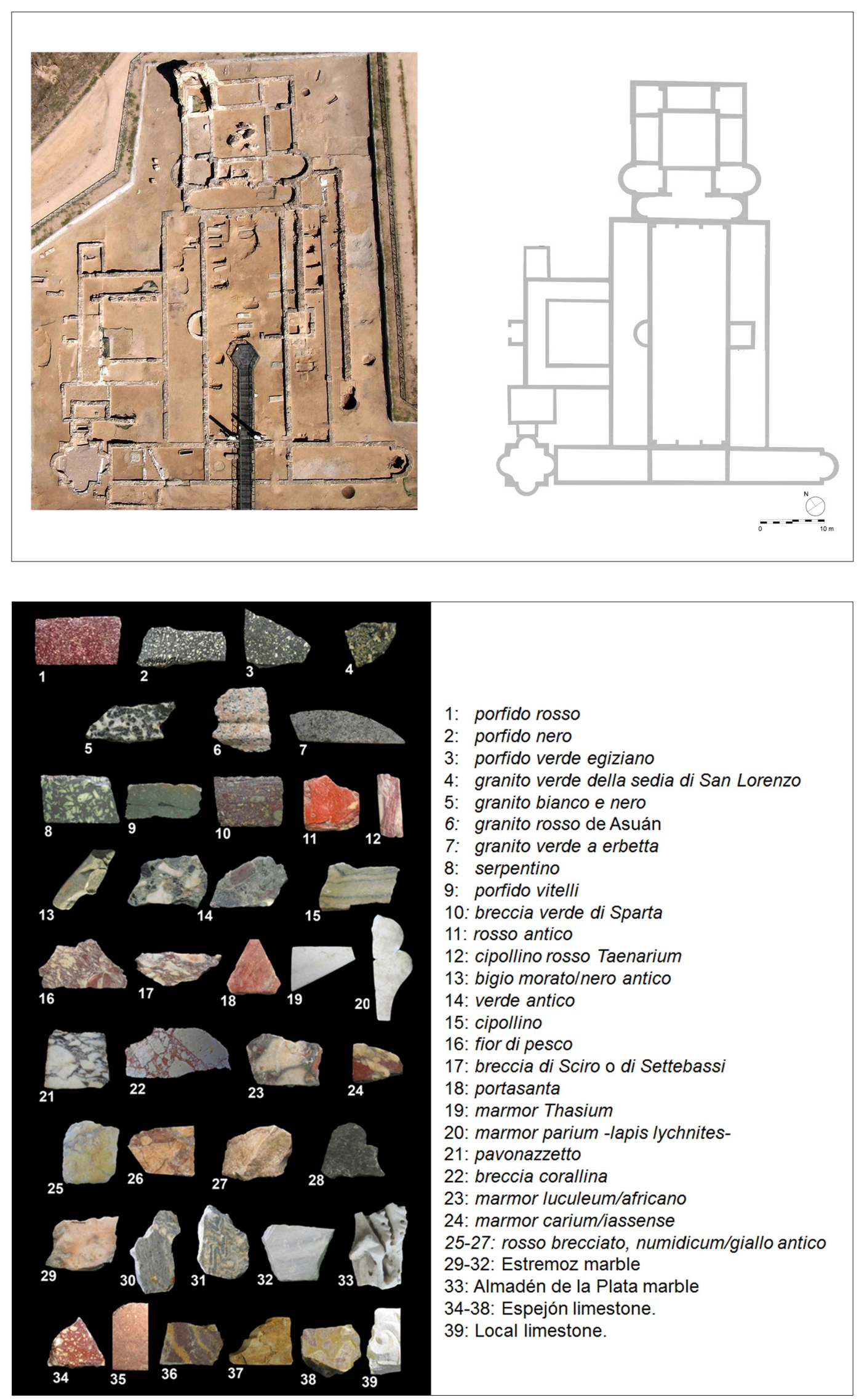

Fig. 2.

Aerial view and plan of the Late Roman palatial building of Carranque
Fig. 3.

Varieties of marmora employed in the Late Roman palatial building decoration program 


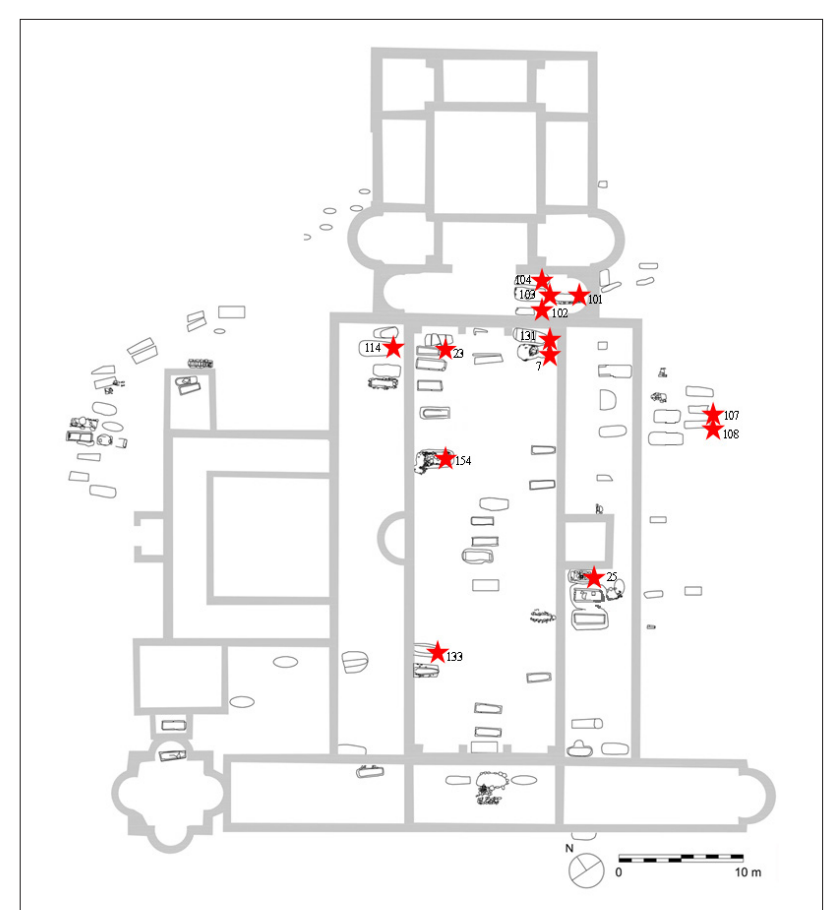

Fig. 4. The Visigothic necropolis sited over the Late Roman palatial building with indication of graves where reused marmora is attested

GARCÍA-ENTERO et al. 2008). The architectural plan and the decoration program of this important building demonstrates the prominent role that architecture and the massive use of marmora played in the self-representation strategies of the Late Roman elite.

In the $6^{\text {th }}-7^{\text {th }}$ centuries $\mathrm{AD}$, a necropolis emerged in the area previously occupied by the palatial building (Fig. 4). This necropolis has at least 110 graves that were excavated between 1988 and 2011 in two different periods of research. The excavation works carried out between 2009 and 2011, and the study of the material unearthed then, which was carried out in 2014, have provided data on the structural features of the tombs, the funeral ritual issues, the use of the necropolis and the anthropological features of the people buried (GARCÍA-ENTERO et al. 2017).

\section{The reuse of marble}

In this paper we focus on the marmora from the Late Roman building found in a secondary position (reused) in the funerary structures (cists and lids) as well as within the filling layers deposited when the tombs were closed, in Visigothic times. The excavation works carried out in 2009 and 2011 confirm the regular reuse of marbles to set up tombs. In this period, 41 Visigothic graves were excavated. Thus, the reuse of marmora from the palatial building to set up the cists or to function as lids (or part of the lids) has been attested in 6 of them (tombs 7 , $25,101,102,114$ and 154), while the presence of marmora fragments within the filling deposits sealing the grave has been corroborated in the case of tombs 7, 23, 101, 103, $104,107,108,131,133$, and $154^{4}$.

In fact, not only marble crustae, opera sectilia fragments and pavement and revetment slabs, but also fragments of opera sectilia preparatory beds were used again in the tombs, as can be seen in the cist walls of tombs No 25 and 102 (Fig. 7). This demonstrates the significant degree of destruction of the late Roman building during the Visigothic period. The varieties of marmora reused in the Visigothic tombs are the more frequent types employed in the palatial decoration program. Thus, porfido rosso, serpentino, giallo antico/giallo brecciato, pavonazzetto, verde antico, Estremoz marble and Espejón limestone were frequently used. However, other less frequent types (cipollino, marmor iassense, rosso antico, portasanta, breccia di Skyros, breccia corallina and slate) were also used, but their presence is barely testimonial. So far, there has been no evidence of the reuse of the most rarely employed marmora, such as porfido nero, porfido verde egiziano, granito verde della sedia di San Lorenzo, granito bianco e nero, granito rosso from Aswan, granito verde a erbetta, breccia verde di Sparta, bigio morato/nero antico, fior di pesco and africano. In this sense, tomb No. 131 stands out for the large

In tomb No 23 only 1 fragment of pavonazzetto was attested. In tomb No 101 there were documented 3 pieces of giallo antico, 2 of serpentino, 2 of Estremoz marble, and 1 piece of porfido rosso, pavonazzetto and verde antico. In tomb No 102 pieces and fragments of giallo antico (13), slate (12), serpentino (7), pavonazzetto (4), verde antico (2) and local white limestone (2) were attested. In tomb No 103 fragments and complete pieces of serpentino (17), giallo antico and giallo brecciato (15), porfido rosso (8), verde antico (7), pavonazzetto (5), breccia di Skyros (1) and Estremoz marble (1) were documented. In tomb No 104, fragments and pieces of slate (24), giallo antico (21), serpentino (15), porfido rosso (8), pavonazzetto (7), verde antico (5), Espejón limestone (3), Estremoz marble (3) cipollino (2) and iassense (1) were attested. It is especially worth noting the reuse of a fragment of opus sectile composition (slate and white marble) in the cist of this tomb (Fig. 7). In tomb No 107 only 1 fragment of porfido rosso, 1 fragment of serpentino and 1 fragment of pavonazzetto are attested. In tomb No 108 only 2 fragments (pavonazzetto and verde antico) are documented. In tomb No $114 \mathrm{a}$ large fragment of giallo antico revetment slab was reused for the grave's lid. In tomb No 133, 7 fragments and complete pieces of serpentino and 1 fragment of pavonazzetto were attested. In Tomb No 154 fragments and complete pieces of pavonazzetto (6), verde antico (4), giallo antico (4), Espejón limestone (2), Estremoz marble (2), serpentino (1) and white local limestone (1) were documented. For the marbles reused in tombs No 7, 25 and 131 see below. 


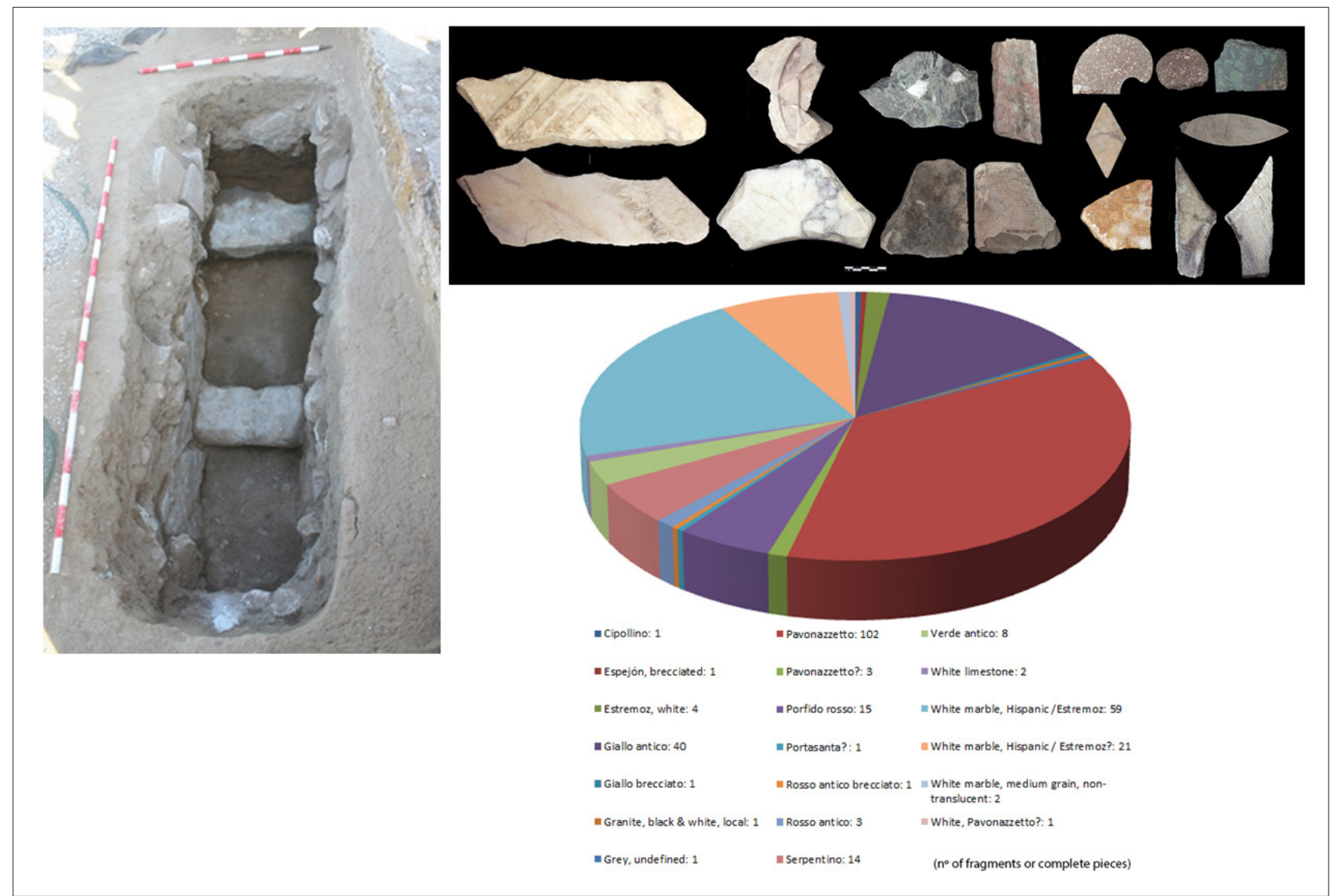

Fig. 5. Tomb nº 131 where 281 marmora fragments were reused.

Right: (above) some of the crustae and revetment panels from tomb $\mathrm{n}^{\circ} 131$ and (down) detail of the marmora varieties reused

number of marmora fragments (281) reused in it, both as material to build the cist and as part of the refilling deposit to seal the tomb (Fig. 5). This tomb is located in the northeast corner of the courtyard of the palatial building and it contained three corpses: an adult individual (between 25 and 35 years old) in primary position and two other individuals (an adult and a child) in secondary position burial. Once again, pavonazzetto, Estremoz marble, giallo antico, porfido rosso and serpentino are the more frequently found marbles, both as fragments and complete pieces of opera sectilia crustae, pavement slabs and wall revetment panels. Most of them show tool marks (saw, pick and chisel), as well as traces of retouching and re-cutting with a chisel. Nevertheless, these tool marks belong to their first period of use, evidencing the cutting and assembling of these marble pieces in order for them to fit perfectly in their intended place in the Late Roman Palace.

Apart from the reuse of marble as mere building material for the graves, we have also detected the careful selection of certain pieces that were incorporated into the structure of some particular graves in an action that can be considered the symbolic use of spolia. This is the case, for example, with tombs $\mathrm{n}^{\circ} 7$ and 25 . Tomb $\mathrm{n}^{\circ} 7$ is located in the Northeast corner of the central courtyard of the palatial building. It is the grave of a child (c. 12 years old), in which a big ${ }^{5}$ Late Roman (late $4^{\text {th }} \mathrm{c}$. AD) sarcophagus marble lid was reused as part of the cover of this tomb, which dates from the $7^{\text {th }}$ c. AD (Fig. 6). The front of the sarcophagus lid is decorated with three scenes taken from the cycle of the prophet Jonah. Archaeometric analysis consisting of POM, CL and IRMS was conducted at the ICAC (Tarragona) and confirmed that the marble used is Estremoz marble (Portugal). We are therefore dealing with a piece made by a Hispanic sculpture workshop of excellent quality that was active in the final decades of the $4^{\text {th }} \mathrm{c}$. AD (FERNÁNDEZ OCHOA et al. 2011; VIDAL, GARCÍA-ENTERO 2015; VIDAL et al. 2016). Although there is no information, it is possible that this magnificent artwork was originally located in the nearby funerary building situated $400 \mathrm{~m}$ south of the palace where other sarcophagus fragments were discovered (GARCÍA-ENTERO, VIDAL 2012). It must be pointed out that a verde antico slab was also employed as part of this closing cover. Moreover, fragments and complete pieces of pavonazzetto, porfido, serpentino, verde antico, Estremoz marble and slate were also found in the deposit sealing the tomb.

Tomb n ${ }^{\circ} 25$ is located in the central part of the east corridor of the palace. It is a children's cist tomb (c. 4 years 


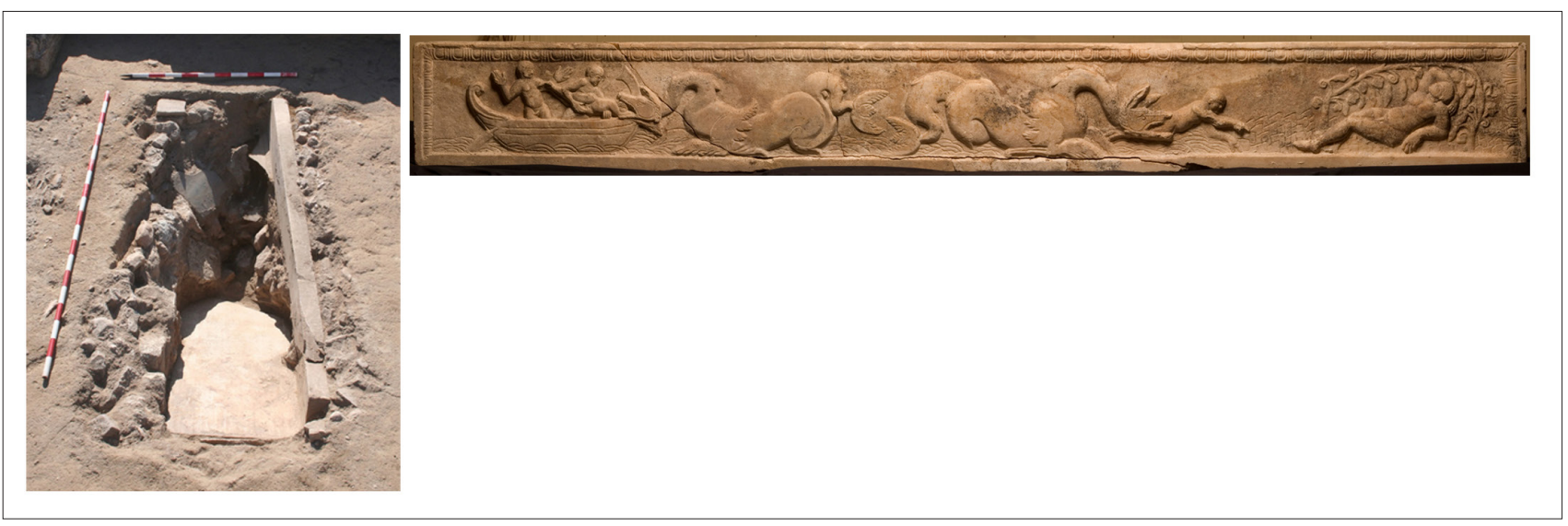

Fig. 6. Sarcophagus lid in Estremoz marble with Jonahesque iconography (late $4^{\text {th }}$ century AD) reused in Tomb $n^{\circ} 7$ ( $7^{\text {th }}$ century AD)

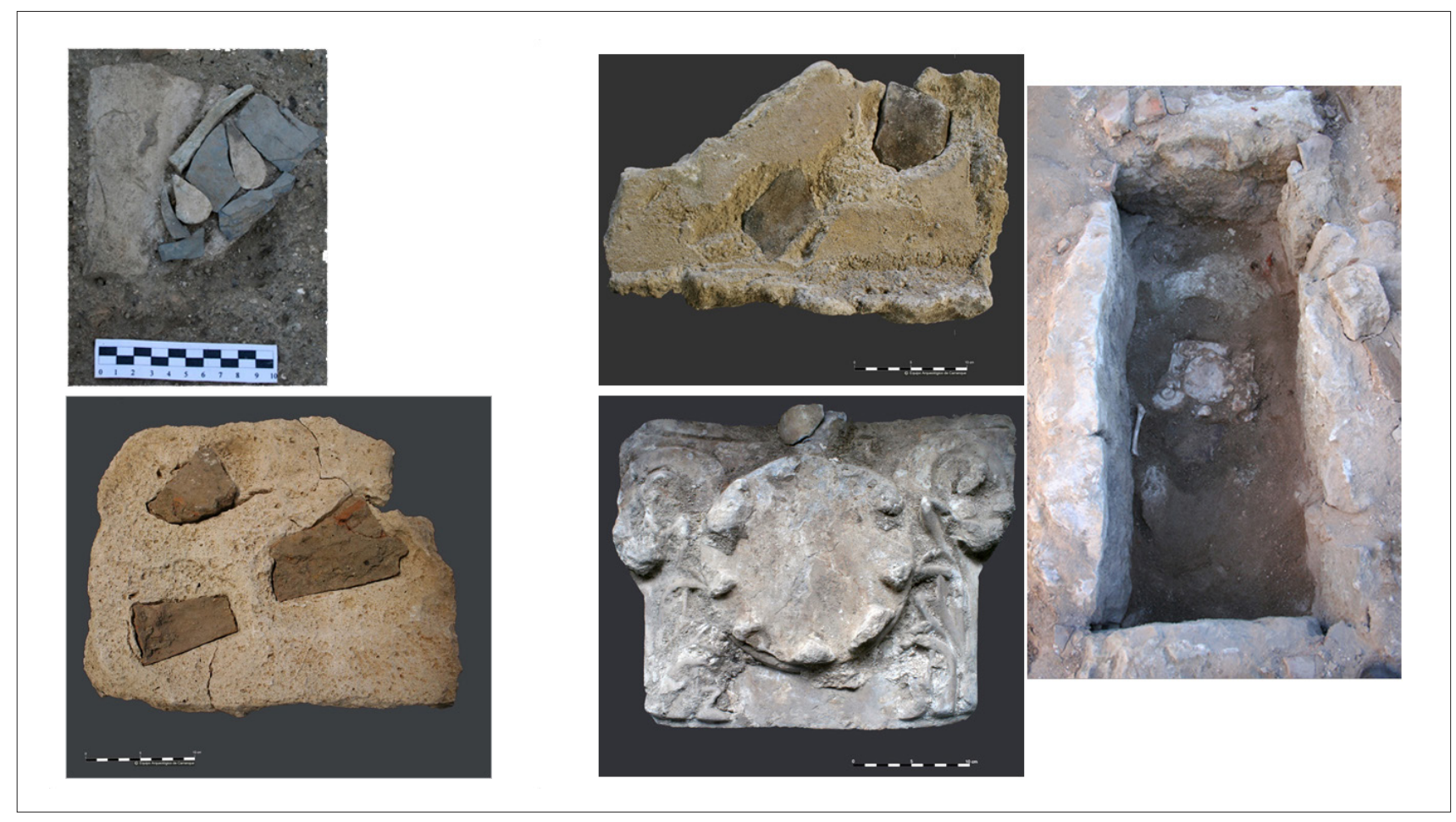

Fig. 7. The reuse of marmora in Visigothic tombs

Left above: Tomb no 104: Opus sectile fragment reused in the construction of the cist

Left down: Tomb no 102: Opus sectile preparatory bed used for the construction of the tomb Right: Tomb no 25: Opus sectile preparatory bed and pavonazzetto pilaster capital reused in the structure of the tomb

old) where an unbroken, pavonazzetto pilaster capital was reused (Fig. 7). This marble piece was carefully placed in the bottom of the grave acting as a sort of bed for the corpse, which was then placed on it. The closing cover of this grave was made of several fragments and complete pieces of crustae and slabs (Estremoz marble, breccia corallina and marmor isassense) as well as a fragment of opera sectilia preparatory bed as mentioned above.

The study of these materials entailed not only the specific identification and recording of all the pieces of marmora, which are currently part of a comprehensive database of the assemblage, but also the detailed examination of traces of use that could help to recognize the primary use of these fragments (GARCÍA-ENTERO et al. 2008). Therefore, the results do not only help to deepen our understanding of the construction processes of the Visigothic cemetery but also to get a more complete image of the volume of marmora originally used at the palatial building of Carranque. 


\section{BIBLIOGRAPHY}

ÀlVAREZ A., GUTIÉRREZ GARCÍA-M. A., PITARCH A. 2006: Informe del análisis por microscopía de polarización de 5 muestras procedentes del yacimiento arqueológico de Carranque (Toledo), Institut Català d'Arqueologia Clàssica, Unitat d'Estudis Arqueomètrics, Tarragona (Unpublished Report).

ÀlVAREZ A., RODÀ I., GUTIÉRREZ GARCIA-M. A., PITARCH A. 2007: Informe del análisis de un conjunto de materiales lapídeos (marmora) procedentes del Parque Arqueológico de Carranque, Toledo, Institut Català d'Arqueologia Clàssica, Unitat d'Estudis Arqueomètrics, Tarragona (Unpublished Report).

FERNÁNDEZ OCHOA C., BENDALA M., GARCÍAENTERO V., VIDAL S. 2011: "Cubierta de sarcófago con el ciclo de Jonás hallada en Carranque (Toledo)", AEspA 84, 231-242.

GARCÍA-ENTERO V., VIDAL S. 2007: "Marmora from the Roman site of Carranque (Toledo, Spain)", Marmora 3, 53-69.

GARCÍA-ENTERO V., VIDAL S. 2012: "El uso del marmor en el yacimiento de Carranque (Toledo)", in V. GARCÍA-ENTERO (ed.): El marmor en Hispania: explotación, uso y difusión en época romana, Madrid, 135-153.

GARCÍA-ENTERO, V., SALÁN, M., VIDAL, S. 2008: "El marmor en el yacimiento de Carranque (Toledo). Algunas consideraciones sobre las marcas de herramientas", in T. NOGALES, J. BELTRAN (eds.): Marmora Hispana: explotación y uso de los materiales pétreos en la Hispania Romana, Roma, 199-211.

GARCÍA-ENTERO V., PEÑA Y., FERNÁNDEZ OCHOA C., ZARCO E. 2012: "La producción de aceite y vino en el interior peninsular. El ejemplo de la villa de Carranque (Toledo"), in J. M. NOGUERA, J. A. ANTOLINOS (eds.): De vino et oleo Hispaniae. Áreas de producción y procesos tecnológicos del vino y el aceite en la Hispania romana. Coloquio Internacional (Murcia-5-7 de mayo de 2010), Murcia, APA 27-28, 155-172.
GARCÍA-ENTERO V., FERNÁNDEZ OCHOA C., PEÑA Y., ZARCO E. 2014: "La evolución arquitectónica del edificio palacial de Carranque (Toledo, España). Primeros avances", in P. PENSABENE, C. SFAMENI (a cura di): La villa restaurata e i nuovi studi sulledilizia residenziale tardoantica, Atti del Convegno Internazionale del CISEM (Piazza Armerina, 7-10 Novembre 2012), Bari, 2014, 477-486.

GARCÍA-ENTERO V., PEÑA Y., ZARCO E., ELVIRA A., VIDAL S. 2017: "La necrópolis de época visigoda de Santa María de Abajo (Carranque, Toledo", in La Meseta Sur entre la Tardía Antigüedad y la Alta Edad Media, Toledo, 153-212.

RODÀ I., ȦLVAREZ A., DOMĖNECH A. 2009: Informe de una muestra de mármol procedente de un sarcófago de Carranque (Toledo), Institut Català d'Arqueologia Clàssica. Unitat d'Estudis Arqueomètrics, Tarragona (Unpublished Report).

RODẢ I., ÀLVAREZ A., DOMËNECH A. 2010: Informe del análisis de un conjunto de muestras de marmora procedentes de Carranque (Toledo), Institut Català d'Arqueologia Clàssica. Unitat d'Estudis Arqueomètrics, Tarragona (Unpublished Report).

VIDAL S., GARCÍA-ENTERO V. 2012: "The use of Estremoz marble in Late Antique Sculpture of Hispania: New Data from the Petrographic and Cathodoluminiscence analyses", in ASMOSIA X, 413-420.

VIDAL S., GARCÍA-ENTERO V., GUTIÉRREZ GARCIA-M. A. 2016: "La utilización del mármol de Estremoz en la escultura hispánica de la Antigüedad Tardía: los sarcófagos", digitAR - Revista Digital de Arqueologia, Arquitectura e Artes (XI Congreso Peninsular de Arqueometría, Evora, octubre 2015), $\mathrm{n}^{\circ} 3,119-128$. 